https://helda.helsinki.fi

\title{
Leaching of Mercury from Peat Soil
}

\section{Lodenius, M.}

Pergamon Journals Ltd.

1987

Lodenius, M. et al. 1987. Leaching of Mercury from Peat Soil. Chemosphere, Vol. 16, no. 6, pp. 1215-1220.

http://hdl.handle.net/1975/204

Downloaded from Helda, University of Helsinki institutional repository.

This is an electronic reprint of the original article.

This reprint may differ from the original in pagination and typographic detail.

Please cite the original version. 
LEACHING OF MERCURY FROM PEAT SOIL

\author{
Martin Lodenius, Ari Seppänen \& Sari Autio \\ Department of Environmental Science \\ University of Helsinki \\ SF-00710 Helsinki, Finland
}

\begin{abstract}
The factors influencing the sorption and leaching of mercury in peat soil were studied using small additions of labelled mercury in peat lysimeters. Additions of chloride, fertilizer or sterilant did not affect the leaching of mercury. Complete drying of the peat improved the leaching of mercury probably because of changes in the physical properties of the peat soil.
\end{abstract}

\title{
Introduction
}

The mobilization of mercury from soil in connection with flooding, draining and ditching is a serious problem in many northern countries 1,2 . The mobilization process is poorly known, but certain humic substances seem to play an important role in both sorption and transport of mercury. The most important reason for the high mercury contents in fish from man-made lakes seems to be organic matter dissolved from the inundated soil3,4. The release of humic matter from the soil into the lakes is greatly promoted by ditching. The two-fold increase in mercury contents of pike from south and central Finnish lakes is however estimated to be caused primarily by the increased deposition of mercury from the atmosphere ${ }^{5,6}$.

The sorption of mercury to soil humus is strong but leaching is promoted by increase of the chloride content and the amount of water. It is decreased by acidification and fertilizing ${ }^{7}$. This laboratory work is a direct continuation of the above mentioned study.

\section{Material and methods}

The experiments were performed using polyethylene lysimeter columns filled with peat7. Mercury was added superficially as 203 $\mathrm{Hg}$-acetate. $10.5 \mu \mathrm{Ci}$ of the tracer was added to each column mixed with the carrier so that the total amount of added mercury was $100 \mu \mathrm{g}$.

The sphagnum peat was slightly humificated (v. Post H2). The pH (CaCl2) was 3.6, the carbon content 448 and the nitrogen content 1.48 (Hewlett-Packard 185B-C-N-analyzer). The $\mathrm{E}_{4} / \mathrm{E}_{6}-\mathrm{ratio}$ (aborbances at 465 and $665 \mathrm{~nm}$ in $\mathrm{NaHCO}_{3}-$ leachate) was 12 indicating a high portion of small-molecular-weight materials (fulvic acids). 
The following treatments were made to 16 peat columns (Table 1):

- KCl to give a chloride concentration in the irrigation water of $20 \mu M$ or $200 \mu \mathrm{M}$,

- fertilizer: $190 \mathrm{mg} \mathrm{KNO}_{3}$ and $397 \mathrm{mg} \mathrm{Ca}\left(\mathrm{PO}_{4}\right)_{2}$ per column).

- sterilant: $\mathrm{NaN}_{2}, 200 \mathrm{mg} / \mathrm{kg}$ (w.w.) of soil,

- water: $50 \mathrm{ml}$ in the beginning, thereafter $20 \times 160 \mathrm{ml}$ (corresponding to 60 mm of precipitation) except the E-columns, to which no water was added after the first $50 \mathrm{ml}$ until the end of the experiment, when they got the rest of the total amount $(3250 \mathrm{ml})$ and the F-columns, which were flooded (bottom of the columns kept closed) until the end of the experiment and thereafter added as much water as to the other columns. The length of the experiment was $71 \mathrm{~d}$.

The leachates were collected periodically during the experiment and the volume, $\mathrm{pH}$, colour (absorbance at $420 \mathrm{~nm}$ ) and $20{ }^{\mathrm{Hg}}$-activities were measured. The mercury contents of the leachates and the columns were measured using a gamma-sample counter (Ultrogamma 1280; Wallac Co., Finland).

Table 1. Scheme for the experimental treatments (duplicate columns).

$\begin{array}{cccccc}\text { Columns } & \text { Steril. } & \text { Cl- } 20 & \text { Cl-200 } & \text { Fertil. } & \text { Dried Flooded } \\ \text { A } & + & + & & + & \\ \text { B } & & + & & & \\ \text { C } & & + & & + & \\ \text { D } & & & & & + \\ \text { E } & & & & & + \\ \text { F } & & & + & & \\ \text { G } & & & + & +\end{array}$

\section{Results and discussion}

As expected, most of the added mercury was bound to the uppermost layer of the peat columns (Figs 1 - 3). The mercury distribution was quite similar in all columns and resembled those observed earlier 7,8. The mercury distribution was almost the same irrespective of the significant differences in watering (regular watering - drying - flooding). In spite of this clear differences occurred between the amounts of mercury leached through the columns.

The small chloride additions, which were near the chloride levels in natural precipitation $(C 1-20)$ and lake water (Cl-200), did not cause any significant mobilization of mercury like bigger additions do $7,9,10$. Consequently it seems unlikely that the chloride content of precipitation (even a polluted one) could increase the leaching of mercury from a peat soil. In three African soils a greater sorption tendency was found for an organic (2-methoxyethyl) mercury chloride species than for an inorganic one $\left(\mathrm{HgCl}_{2}\right){ }^{10}$.

The addition of sterilant did not affect significantly the sorption of mercury, nor had the drying and flooding any clear effects on the binding. The reduced leaching and increased evaporation of mercury in fertilized columns was thought to be caused by an increased microbial activity. However, in this experiment the addition of fertilizer did not have any significant effect on the sorption of mercury. Possibly the microbial activity was much less in these columns? 


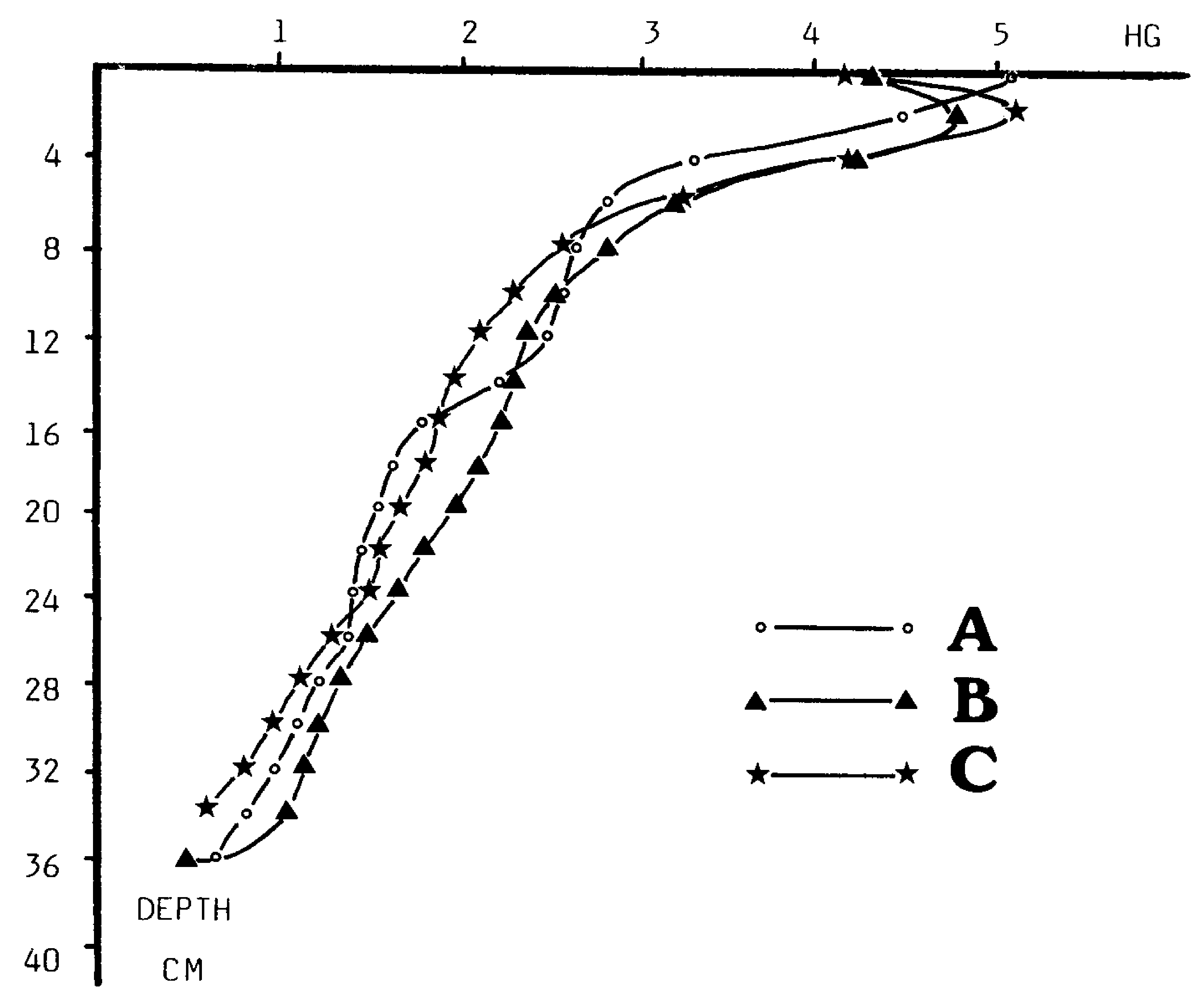

Fig. 1. Sorption of mercury (log scale) in the peat columns at different depths and different treatments: $\mathrm{Cl}-20$ + fertlizer + sterilant (A), $\mathrm{Cl}-20$ (B) and Cl20 + fertilizer (C).

The leaching of mercury was greatest when the peat soil was allowed to dry completely (E-columns; Fig.4). This was probably due to the formation of cracks during drying which allowed mercury bound to suspended organic material to pass the column very quickly. It is not easy to compare laboratory results to natural physical, chemical and biochemical processes, but these results indicate the possibility of a pathway for mercury from deeper soil layers to the surface after drying of the shores in man-made lakes.

A little smaller but regular mercury leaching was obtained from the D-columns, which got destilled water only. In a laboratory experiment verta et al. 10 found that the release of mercury from peat is greatest under anaerobic conditions. From our flooded F-columns no mercury was leached, probably because of the formation of HgS or unsoluble organic complexes under anaerobic conditions. From the other columns no or only small amounts of mercury were obtained during the first month of the experiment. 


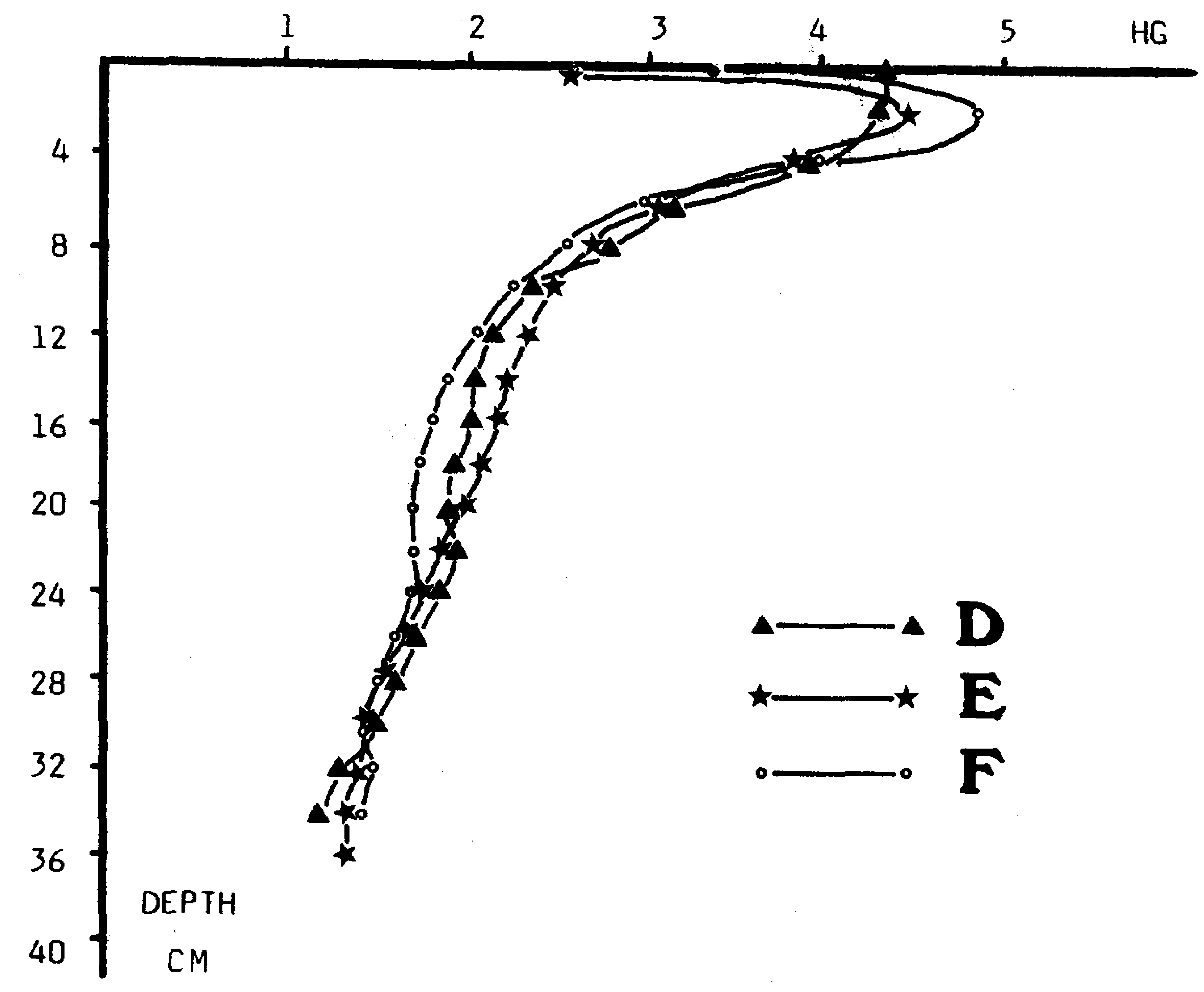

Fig. 2. Sorption of mercury (log scale) in the peat columns at different depths and different treatments: control (D), drying and flooding (E) and flooding (F). 


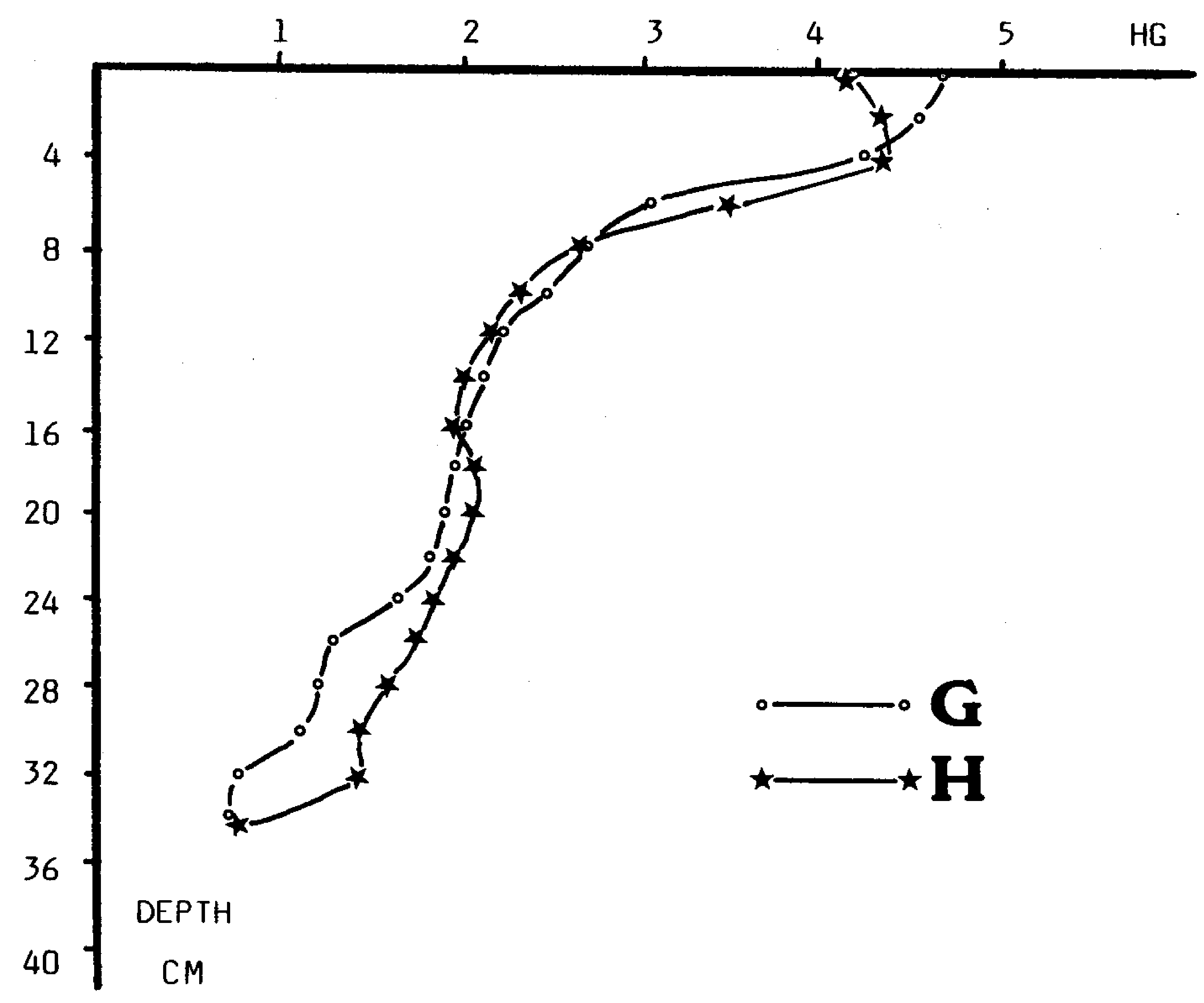

Fig. 3. Sorption of mercury ( $\log$ scale) in the peat columns at different depths and different treatments: $\mathrm{Cl}-200$ (G) and $\mathrm{Cl}-200$ + fertilizer (H).

\section{Acknowledgements}

We are indebted to Jouko Sare'n, Esa Tulisalo and Antti Uusi-Rauva for technical assistance. We also thank the Finnish Foundation for Reasearch of Natural Resources and the Academy of Finland for financial support.

\section{References}

1. Lodenius M, Seppänen A \& Herranen M: Water Air Soil Pollut 19:237 (1983).

2. Bodaly RA, Hecky RE \& Fudge JP: Can J Fish Aquat Sci 41:682 (1984).

3. Mannio J, Verta J, Kortelainen P \&ekolainen S: PubI Water Res Inst, Nat Bd Waters Finland 65: 32 (1986).

4. Verta $M$, Rekolainen $S$ \& Rinnunen $K$ : Publ Water Res Inst, Nat Bd Waters Finland 65: 44 (1986).

5. Rekolainen $S$, Verta $M$ \& Liehu A: Publ Water Res Inst, Nat Bd Waters Finland 65: 11 (1986).

6. Verta M, Rekolainen $S$, Mannio $J$ Surma-Aho K: Publ Water Res Inst, Nat Bd waters Finland 65:31(1986).

7. Lodenius M, Seppänen A \& Uusi-Rauva A: Chemosphere 12:1575 (1983).

8. Semu E, Singh BR \& Selmer-Olsen AR: Water Air Soil Pollut 27:19 (1986).

9. Zvonarev BA \& Zyrin NG: Vestnik Moskov Univ, Pochvovedenie 38(3):29 (1983).

10. SemuE, Singh BR, Steenberg $R$ \& Selmer-olsen AR: Acta Agric Scand $35: 129$ (1985). 


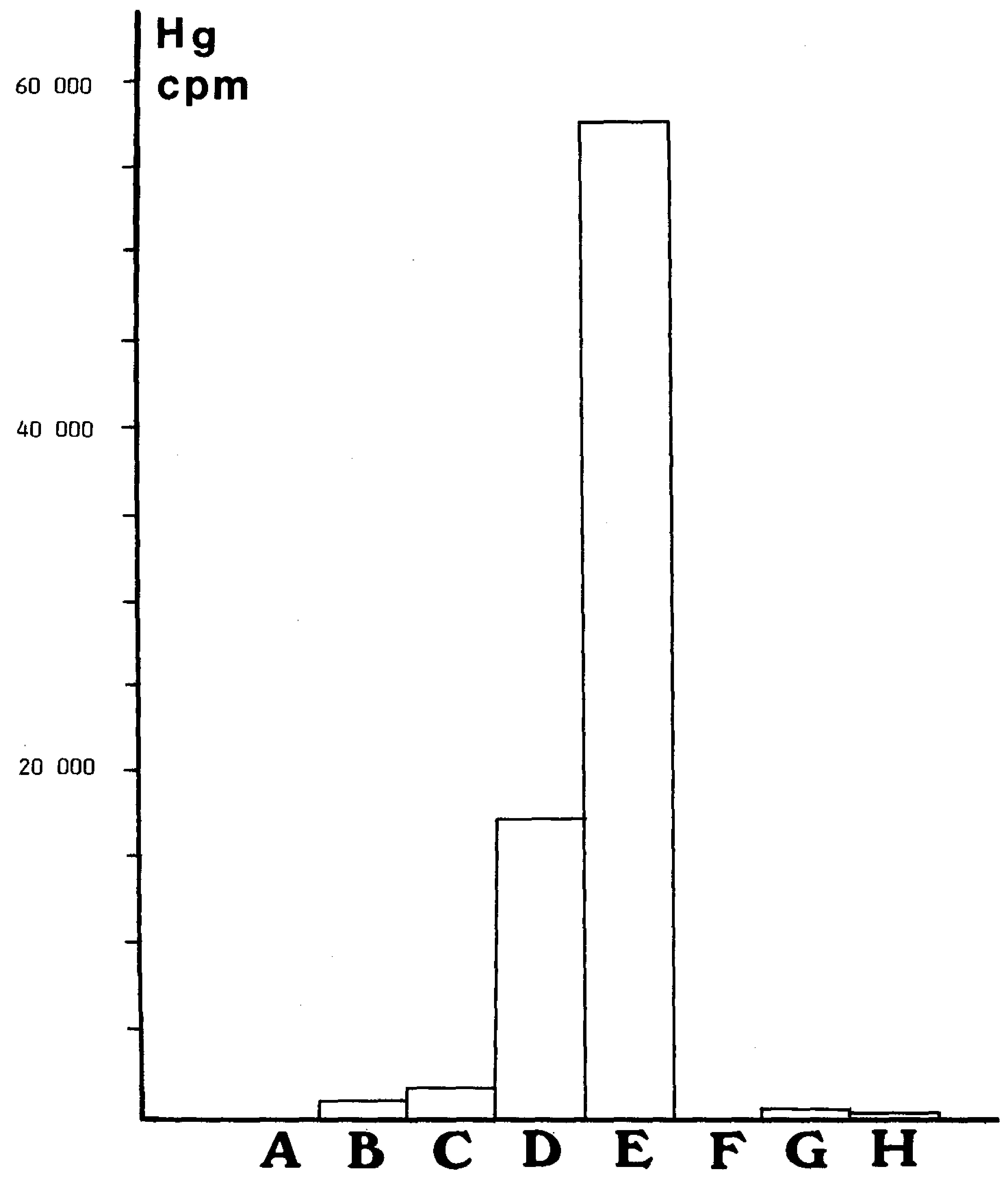

Fig. 4. Leaching of mercury (cpm) from the peat columns

$A=C l-20+$ fertil. + steril.

$B=C l-20$

$C=C l-20+$ fertil.

D $=$ Control

$\mathrm{E}=$ Drying

$F=$ Flooding

$\mathbf{G}=\mathrm{Cl}-200$

$\mathrm{H}=\mathrm{Cl}-200+$ fertil.

(Received in Germany 29 December 1986; accepted 10 March 1987) 